\title{
NEUROPROTECTIVE EFFECT OF ANACARDIUM OCCIDENTALE (CASHEW APPLE FRUIT) AGAINST ALUMINUM TOXICITY: AN EXPERIMENTAL STUDY ON COGNITIVE DYSFUNCTION AND BIOCHEMICAL ALTERATIONS IN RATS
}

\author{
BHAGYASREE P*, KALYANI G \\ Department of Pharmacology, University College of Pharmaceutical Sciences, Acharya Nagarjuna University, Nagarjuna Nagar, \\ Andhra Pradesh, India. Email: gadekalyani1989@gmail.com
}

Received: 28 October 2016, Revised and Accepted: 25 November 2016

\section{ABSTRACT}

Objective: To study the protective role of fruit extract of Anacardium occidentale (cashew apple) in aluminum-induced cognitive dysfunction and oxidative damage in albino rat, and to explore the neuroprotective effect of $A$. occidentale represented by behavior and memory tests.

Methods: Male Wistar rats (30) were divided into 5 groups of 6 rats each. Group I received normal saline. Group II was administered orally with aluminum chloride $(100 \mathrm{mg} / \mathrm{kg})$. Group III received rivastigmine $0.3 \mathrm{mg} / \mathrm{kg}$ body orally. Groups IV and V were administered with A. occidentale 200 and $400 \mathrm{mg} / \mathrm{kg}$ along with aluminum chloride of $100 \mathrm{mg} / \mathrm{kg}$ orally after $1 \mathrm{hr}$ interval. The study was carried out for 42 days (6 weeks). The behavioral assessment was performed using Rota-rod apparatus and Elevated plus maze and Biochemical parameters from brain homogenate such as acetylcholinesterase activity, total protein, lipid peroxidation malondialdehyde, superoxide dismutase (SOD), catalase, and glutathione reductase (GR) were estimated. All the data were analyzed using one-way analysis of variance followed by Tukey's multiple comparison test.

Results: The \% reduction of acetylcholinesterase, GR observed in A.0 (400 mg/kg) dose as compared with that of standard drug was found to be $87.5 \%$ and $89 \%$, respectively, whereas \% reduction of catalase and SOD observed in A.O (400 mg/kg) dose as compared with that of standard drug was found to be $97 \%$ and $99 \%$, respectively.

Conclusion: This study demonstrates A. occidentale fruit has a neuroprotective effect against aluminum-induced behavioral changes.

Keywords: Occidentale, Neuroprotective, Alzheimer's disease, Aluminum

(c) 2017 The Authors. Published by Innovare Academic Sciences Pvt Ltd. This is an open access article under the CC BY license (http://creativecommons. org/licenses/by/4. 0/) DOI: http://dx.doi.org/10.22159/ajpcr.2017.v10i3.15937

\section{INTRODUCTION}

Alzheimer's is a degenerative and terminal disease for which there is no known cure. In its most common form it effects individuals over 65 years old. Currently, there is no cure for Alzheimer's and no way to stop the underlying death of brain cells. However, drugs and non-drug treatments may help with both cognitive and behavioral symptoms. Today, Alzheimer's is at the forefront of biomedical research, with $90 \%$ of what we know discovered in the past 20 years [1]. Some of the most remarkable progress has shed light on how Alzheimer's disease affects the brain. A better understanding of its impact may lead to better ways to treat it. A comprehensive care plan for Alzheimer's disease [2] involves monitoring treatment effectiveness as the disease progresses, changing course, and exploring alternatives as necessary and respecting individual and family goals for treatment and tolerance for risk.

The Anacardium occidentale has been reported to have immense pharmacological and therapeutic activity. Various research works carried out have proved it to be used in various diseases such as dermatitis, hyperglycemia, antiviral, and anti-inflammatory activity. The fruit juice and tea of the bark are very common diarrhea remedies [3]. The observed anti-inflammatory and anti-diarrheal activities of cashew extracts have been attributed to tannins [4].

Aluminum is a non-redox active metal which is capable of increasing the cellular oxidative milieu [5] by potentiating the pro-oxidant properties of transition metals such as iron and copper [6]. It leads to progressive deterioration of mitochondrial function which culminates into excessive free radical generation eventually resulting in DNA damage, nitration of protein residues, and lipid peroxidation. A. occidentale indicated significant cytoprotective effects against glutamate-triggered cell death in HT22 cells. Based on this background, this study was designed to investigate the neuroprotective effect [7] of $A$. occidentale against aluminum-induced cognitive impairment [8] and associated oxidative damage in rats.

\section{METHODS}

Plant material

The cashew apple fruit species A. occidentale (700 g) was collected from Jangareddygudem, in Andhra Pradesh, India. The sample was then shade dried till constant weight obtained. The fruit of $A$. occidentale was identified and authenticated by Professor Dr. Vatsavaya S. Raju, M.Sc., Ph.D., D.A.S., FBS, FIAT, and the sample was deposited in the Herbarium, Department of Botany, Kakatiya University, Warangal, A.P., with specimen voucher number 1887. The species is known as "Jeedi Mamidi" locally and globally as "cashew nut."

\section{Chemicals}

Aluminum chloride (CDH, India), rivastigmine (Novartis Co, Cairo, Egypt), ethanol $90 \%$, acetylthiocholine iodide, DTNB reagent, Tris buffer, biuret reagent, trichloroacetic acid, potassium phosphate buffer, O-dianisidine solution, potassium dihydrogen and dipotassium hydrogen phosphate, Sodium phosphate buffer, xylene, hematoxylin, Eosin stain.

\section{Animals}

Healthy adult male albino rats of Wistar strain weighing (200-230 g) were chosen from the albino research training institute, Hyderabad, 
India and were used for the experimental purpose. The animals were acclimatized to the standard laboratory conditions with temperature $\left(25 \pm 2^{\circ} \mathrm{C}\right)$ and fed with standard animal pellet feed (Hindustan lever limited), ad libitum. The protocol was approved by the Institutional Animal Ethics Committee (IAEC) constituted for the purpose of animal experimentation as per CPCSEA guidelines (Reg. No. ARTI/CPCSEA/0034-2013), with approval no: (CPCSEA/IAEC/ EXP/25/50/2013/EXP-34) for the care and use of animals

\section{Extraction of plant material}

The fruits (5-6 kg) were cleaned, and the size was reduced by cutting into small parts and were shade dried. They were coarsely powdered with the help of a blender $(300 \mathrm{~g})$. The coarse powder $(250 \mathrm{~g})$ of the fruits was then exhaustively extracted with $500 \mathrm{~mL}$ of ethyl alcohol using a soxhlet apparatus. The extract was concentrated by distilling the solvent and preserved under refrigeration for further studies. The obtained dried extract was further subjected to various chemical tests to detect the presence of different phytoconstituents [9].

\section{Acute toxicity study}

As per the OECD guidelines 423, the acute toxicity [10] of the alcoholic extract of $A$. occidentale was tested on different groups of 10 mice. Each receiving different doses of 50,100, 200, 400, 800, 1000, and $2000 \mathrm{mg} / \mathrm{kg}$ body weight. The number of deaths and behavioral changes were observed in each group and recorded within $48 \mathrm{hrs}$. Up

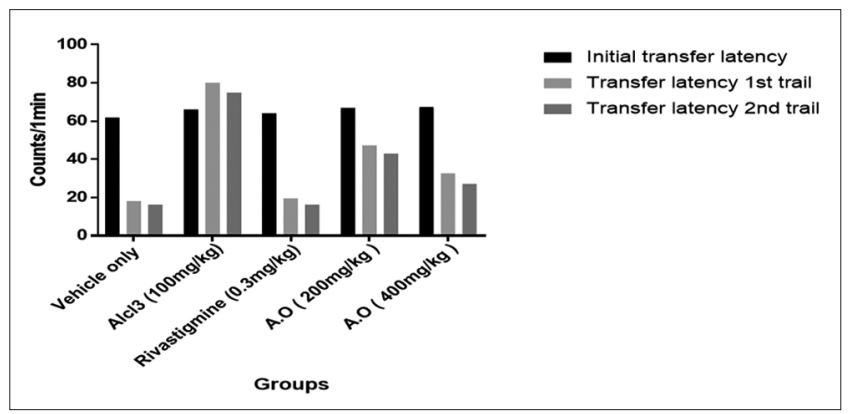

Fig. 1: Performance using elevated plus Maze

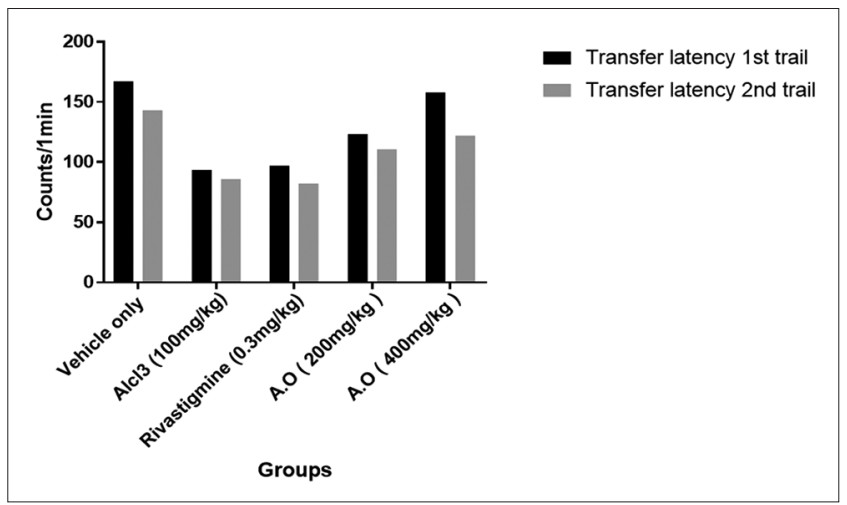

Fig. 2: Effect of muscle relaxant property by using Rota rod method to $2000 \mathrm{mg} / \mathrm{kg}$, there were no signs of toxicity and mortality. Based on these studies, 200 and $400 \mathrm{mg} / \mathrm{kg}$ of $A$. occidentale were chosen for the present experimental study.

\section{Allotment of animals and drug treatment}

Male Wistar rats (30) were divided into 5 groups of 6 rats each by the computerized randomization method.

Group I served as normal control and received normal saline. Group II was administered with aluminum chloride at a dose of $100 \mathrm{mg} / \mathrm{kg}$ through oral route by dissolving in normal saline. Group III was administered with standard drug rivastigmine orally by dissolving in normal saline at a dose of $0.3 \mathrm{mg} / \mathrm{kg}$. Groups IV and V were administered with test drug A. occidentale 200 and $400 \mathrm{mg} / \mathrm{kg}$ along with aluminum chloride at $100 \mathrm{mg} / \mathrm{kg}$ bodyweight through the oral route. The study was carried out for 42 days ( 6 weeks). The drug was administered orally $1 \mathrm{~h}$ after aluminum chloride administration.

\section{Behavioral assessment}

On the day 0,21, 42 behavioral assessment was carried out for Elevated plus Maze and Rota-rod apparatus.

\section{Muscle relaxant property by using rota-rod method}

Turn on the Rota-rod by selecting an appropriate speed (20-25 rpm). Place the animal one by one into several compartments. Note down the "fall off time" when the rat falls from the Rotating rod. A normal group of rats generally falls off within 3-5 minutes. Later the treated groups are followed by noting the fall off time.

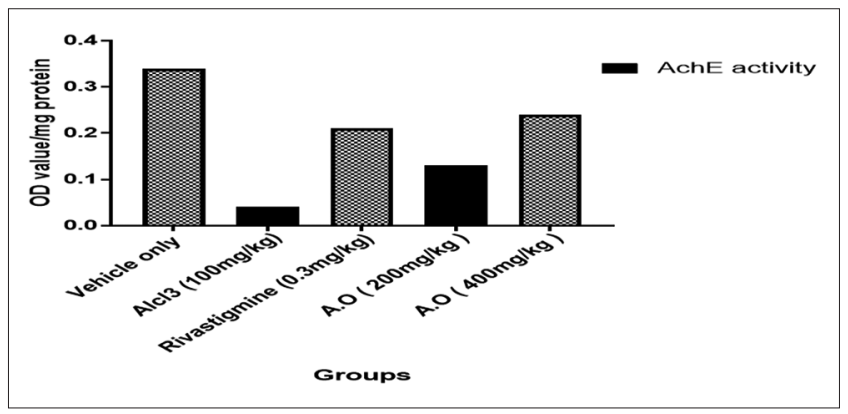

Fig. 3: Estimation of acetyl cholinesterase activity

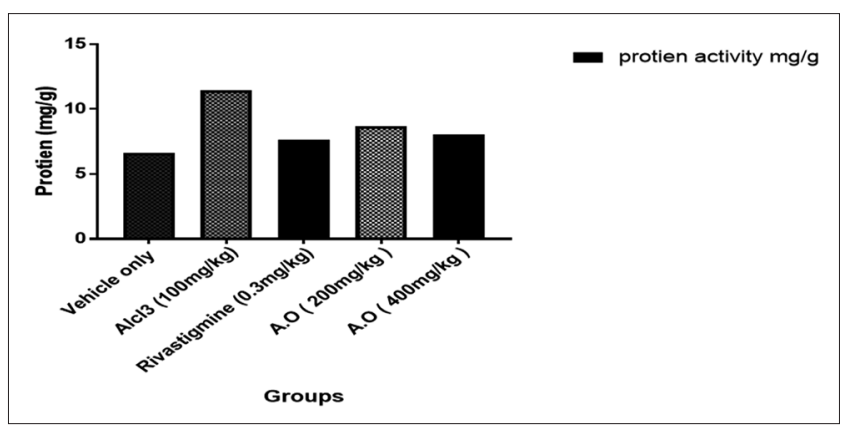

Fig. 4: Estimation of total protein

Table 1: Performance using elevated plus Maze

\begin{tabular}{|c|c|c|c|c|}
\hline Groups & Treatment & Initial transfer latency & Transfer latency $1^{\text {st }}$ trial $\left(21^{\text {st }}\right.$ day $)$ & Transfer latency $2^{\text {nd }}$ trial $\left(42^{\text {nd }}\right.$ day $)$ \\
\hline Group I & Vehicle only & $61.90 \pm 0.55$ & $18.02 \pm 0.22$ & $16.02 \pm 0.44$ \\
\hline Group II & $\mathrm{Alcl}_{3}(100 \mathrm{mg} / \mathrm{kg})$ & $66.13 \pm 1.04$ & $79.98 \pm 1.11^{*}$ & $74.98 \pm 0.92^{*}$ \\
\hline Group III & Rivastigmine $(0.3 \mathrm{mg} / \mathrm{kg})$ & $64.00 \pm 0.63$ & $19.48 \pm 0.41^{\$}$ & $16.05 \pm 0.47^{\$}$ \\
\hline Group IV & A.O (200 mg/kg) & $66.73 \pm 0.61$ & $47.34 \pm 1.32^{\text {sa }}$ & $42.84 \pm 1.02^{\text {\$a }}$ \\
\hline Group V & A. $(400 \mathrm{mg} / \mathrm{kg})$ & $67.12 \pm 0.77$ & $32.59 \pm 0.60^{\$}$ & $27.09 \pm 1.79^{\$}$ \\
\hline
\end{tabular}

Values were expressed as mean $\pm S E M$ of each group $(\mathrm{n}=6)$ and were significant when done One-way ANOVA with Tukey's post hoc test. ${ }^{*} \mathrm{p}<0.001$ when compared with normal, ${ }^{\mathrm{s}}<0.001$ with positive control, $\mathrm{a}<<0.001$ with the standard, SEM: Standard error mean 
Performance on elevated plusMaze

The elevated plus maze consisted of two opposite black open arms $(50 \times 10 \mathrm{~cm})$, crossed with two closed walls of the same dimensions with $40 \mathrm{~cm}$ high walls. The arms were connected to a central square of dimensions $10 \times 10 \mathrm{~cm}$ the entire maze was placed $50 \mathrm{~cm}$ high above the ground. Acquisition of memory was tested on day 20 from the start of aluminum chloride administration. Rats were placed individually at one end of the open arm facing away from the central square. The time taken by the animal to move from the open arm to the closed arm was recorded as the initial transfer latency (ITL). Retention of memory was assessed by placing the rat in an open arm and the retention latency was noted on day 21 and day 42, respectively.

\section{Biochemical assessment}

Biochemical tests were conducted 24 hrs after the last behavioral test. The animals were sacrificed by decapitation; the brains were removed, weighed and kept on ice. A $10 \%(\mathrm{w} / \mathrm{v})$ tissue homogenate was prepared in $0.1 \mathrm{M}$ phosphate buffer $(\mathrm{pH} 7.4)$ using Teflon tissue homogenizer at $1000 \times \mathrm{g}$ for 20 minutes at $4^{\circ} \mathrm{C}$. The homogenate so obtained was used for the assessment of biochemical parameters [11] such as acetylcholinesterase (AchE) [12] protein, lipid peroxidation malondialdehyde (MDA), superoxide dismutase (SOD), catalase, and glutathione reductase (GR) activities.

\section{Histopathological examination}

The whole brain of the rat was taken and divided into two sections; the first portion was used for biochemical estimation and the second portion of the brain was fixed in formalin buffer (10\%) for 24 hrs. The brains are washed in tap water and then dehydrated using serial dilutions of alcohol. Specimens are cleared in xylene and embedded in paraffin in a hot air oven at $56^{\circ} \mathrm{C}$ for $24 \mathrm{hrs}$. Paraffin beeswax blocks are prepared for sectioning at $4 \mathrm{~mm}$ using a microtome. The obtained tissue sections are collected on glass slide deparaffinized, stained with hematoxylin and eosin stains for histopathological examination using a light microscope.

\section{Statistical analysis}

All the data were expressed as mean \pm standard error mean (SEM) and were analyzed by One-way Analysis of variance (ANOVA) followed by Tukey's multiple comparison test as a post hoc test. The value of

Table 2: Effect of muscle relaxant property by using rota rod method

\begin{tabular}{llll}
\hline Groups & Treatment & $\begin{array}{l}\mathbf{1}^{\text {st }} \text { trial } \\
\left.\mathbf{( 2 1}^{\text {st }} \text { day }\right)\end{array}$ & $\begin{array}{l}\mathbf{2}^{\text {nd }} \text { trial } \\
\left.\mathbf{( 4 2}^{\text {nd }} \mathbf{d a y}\right)\end{array}$ \\
\hline Group I & Vehicle only & $167.3 \pm 2.17$ & $142.7 \pm 5.10$ \\
Group II & Alcl $_{3}(100 \mathrm{mg} / \mathrm{kg})$ & $93.57 \pm 0.70^{*}$ & $85.91 \pm 1.96^{*}$ \\
Group III & Rivastigmine $(0.3 \mathrm{mg} / \mathrm{kg})$ & $96.82 \pm 1.07^{\$}$ & $82.08 \pm 3.30^{\$}$ \\
Group IV & A.O $(200 \mathrm{mg} / \mathrm{kg})$ & $123.0 \pm 0.98^{\$ a}$ & $110.8 \pm 1.66^{\$ a}$ \\
Group V & A.O $(400 \mathrm{mg} / \mathrm{kg})$ & $157.5 \pm 4.61^{\$}$ & $122.0 \pm 4.29^{\$}$ \\
\hline
\end{tabular}

Values were expressed as Mean \pm SEM of each group $(n=6)$ and were significant when done One-way ANOVA with Tukey's post hoc test. ${ }^{*} \mathrm{p}<0.001$ when compared with normal, ${ }^{\$} \mathrm{p}<0.001$ with positive control, ${ }^{\mathrm{a}} \mathrm{p}<0.001$ with the standard, SEM: Standard error mean

Table 3: Estimation of AchE activity

\begin{tabular}{lll}
\hline Groups & Treatment & $\begin{array}{l}\text { AchE activity } \\
\text { (OD value } / \text { mg protein) }\end{array}$ \\
\hline Group I & Vehicle only & $0.34 \pm 0.003$ \\
Group II & Alcl $_{3}(100 \mathrm{mg} / \mathrm{kg})$ & $0.04 \pm 0.02^{*}$ \\
Group III & Rivastigmine $(0.3 \mathrm{mg} / \mathrm{kg})$ & $0.21 \pm 0.004^{\$}$ \\
Group IV & A.O $(200 \mathrm{mg} / \mathrm{kg})$ & $0.13 \pm 0.02^{\$ a}$ \\
Group V & A.O $(400 \mathrm{mg} / \mathrm{kg})$ & $0.24 \pm 0.01^{\$}$ \\
\hline
\end{tabular}

AchE: Acetyl cholinesterase, ${ }^{\$} \mathrm{p}<0.001$ with positive control, ${ }^{\mathrm{a}} \mathrm{p}<0.001$ with standard, ${ }^{*} \mathrm{p}<0.001$ when compared with normal $\mathrm{p}<0.001$ was considered statistically significant. Data were analyzed using Graph Pad prism software.

\section{RESULTS}

For elevated plus maze method

In the elevated plus maze, on the $20^{\text {th }}$ day the initial transfer latency (ITL) was taken and there was no significant variation. Normal control $\left({ }^{*} \mathrm{p}<0.001\right)$ and Anacardium occidentale extract treated $(200 \mathrm{mg} / \mathrm{kg})$ and $(400 \mathrm{mg} / \mathrm{kg}$ ) rats entered closed arm quickly and the mean retention latencies ( $1^{\text {st }}$ RTL $\& 2^{\text {nd }}$ RTL) to enter the closed arms on day 21 and 42 were shorter when compared to ITL. Aluminium chloride treated $\left({ }^{\$} \mathrm{p}<0.001\right)$ rats showed no variation in mean retention latency on $21^{\text {st }}$ and $42^{\text {nd }}$ day when compared to pretrained animals ITL on $20^{\text {th }}$ day. This shows cognitive impairment of aluminium chloride treated animals. The results were observed and showed in the Table 1 and Figure 2.

\section{For rota-rod method}

In rota rod apparatus the fall off time is been recorded for each group of animal and is known to observe on $20^{\text {th }}$ day as initial fall off time. Results provided in the Table 2 and Figure 2 reveals that the standard ( $\left.{ }^{\mathrm{a}} p<0.001\right)$, A. occidentale extract $(200 \mathrm{mg} / \mathrm{kg}) \&(400 \mathrm{mg} / \mathrm{kg})$ showed decrease in fall off time on the $21^{\text {st }}$ day and $42^{\text {nd }}$ day after training. Positive control $\left({ }^{\$} p<0.001\right)$ showed an increase in fall of time when compared to initial fall off time. This shows neurological deficit elicits motor in co-ordination.

\section{For AchE activity}

The \% reduction of acetylcholinesterase observed in A.O (400 mg/kg) dose as compared with that of the standard drug was found to be $87.5 \%$ which was inferred from the Table 3 and Figure 3.

\section{For estimation of total protein}

Table 4 and Figure 4 reveals the \% reduction of total protein observed in A.O (400 mg/kg) dose as compared with that of the standard drug was found to be $95 \%$.

\section{Table 4: Estimation of total protein}

\begin{tabular}{lll}
\hline Groups & Treatment & Protein activity mg/g \\
\hline Group I & Vehicle only & $6.65 \pm 0.07$ \\
Group II & Alcl $_{3}(100 \mathrm{mg} / \mathrm{kg})$ & $11.46 \pm 0.13^{*}$ \\
Group III & Rivastigmine $(0.3 \mathrm{mg} / \mathrm{kg})$ & $7.65 \pm 0.07^{\$}$ \\
Group IV & A.0 $(200 \mathrm{mg} / \mathrm{kg})$ & $8.68 \pm 0.06^{\$ \mathrm{a}}$ \\
Group V & A.0 $(400 \mathrm{mg} / \mathrm{kg})$ & $8.05 \pm 0.09^{\$ c}$ \\
\hline
\end{tabular}

${ }^{\$} \mathrm{p}<0.001$ with positive control, ${ }^{a} \mathrm{p}<0.001$ with standard, ${ }^{*} \mathrm{p}<0.001$ when compared with normal

Table 5: Estimation of lipid peroxidation MDA

\begin{tabular}{lll}
\hline Groups & Treatment & nmole MDA $/$ mg protein \\
\hline Group I & Vehicle only & $110.69 \pm 0.014$ \\
Group II & Alcl $_{3}(100 \mathrm{mg} / \mathrm{kg})$ & $222.40 \pm 0.018^{*}$ \\
Group III & Rivastigmine $(0.3 \mathrm{mg} / \mathrm{kg})$ & $111.72 \pm 0.020^{\$}$ \\
Group IV & A.O $(200 \mathrm{mg} / \mathrm{kg})$ & $150.2 \pm 0.012^{\$ a}$ \\
Group V & A.O $(400 \mathrm{mg} / \mathrm{kg})$ & $115.4 \pm 0.019^{\$ c}$ \\
\hline
\end{tabular}

MDA: Malondialdehyde, ${ }^{\$} \mathrm{p}<0.001$ with positive control, ${ }^{a} \mathrm{p}<0.001$ with standard, ${ }^{*} \mathrm{p}<0.001$ when compared with normal, ${ }^{\mathrm{p}}<<0.001$ with Negative control.

Table 6: Estimation of SOD

\begin{tabular}{lll}
\hline Groups & Treatment & SOD, units $/$ mg protein \\
\hline Group I & Vehicle only & $93.7 \pm 0.013$ \\
Group II & Alcl $_{3}(100 \mathrm{mg} / \mathrm{kg})$ & $26.5 \pm 0.021^{*}$ \\
Group III & Rivastigmine $(0.3 \mathrm{mg} / \mathrm{kg})$ & $91.0 \pm 0.066^{\$}$ \\
Group IV & A.O $(200 \mathrm{mg} / \mathrm{kg})$ & $82.6 \pm 0.023^{\$ a}$ \\
Group V & A.O $(400 \mathrm{mg} / \mathrm{kg})$ & $91.8 \pm 0.042^{\$ c}$ \\
\hline
\end{tabular}

SOD: Super oxide dismutase, ${ }^{\$} \mathrm{p}<0.001$ with positive control, ${ }^{\mathrm{a}} \mathrm{p}<0.001$ with standard, ${ }^{*} \mathrm{p}<0.001$ when compared with normal, ${ }^{c} \mathrm{p}<0.001$ with Negative control. 
Table 7: Estimation of catalase

\begin{tabular}{lll}
\hline Groups & Treatment & $\begin{array}{l}\text { Catalase } \boldsymbol{\mu m o l} \\
\mathbf{H}_{2} \mathbf{O}_{2} / \text { minute } / \mathbf{m g} \text { protein }\end{array}$ \\
\hline Group I & Vehicle only & $97.3 \pm 0.351$ \\
Group II & Alcl $_{3}(100 \mathrm{mg} / \mathrm{kg})$ & $25.05 \pm 0.01^{*}$ \\
Group III & Rivastigmine $(0.3 \mathrm{mg} / \mathrm{kg})$ & $89.7 \pm 0.059^{\$}$ \\
Group IV & A.O $(200 \mathrm{mg} / \mathrm{kg})$ & $74.9 \pm 0.088^{\$ \mathrm{a}}$ \\
Group V & A.O $(400 \mathrm{mg} / \mathrm{kg})$ & $91.9 \pm 0.063^{\$ \mathrm{c}}$ \\
\hline
\end{tabular}

${ }^{\$} \mathrm{p}<0.001$ with positive control, ${ }^{a} \mathrm{p}<0.001$ with standard, ${ }^{*} \mathrm{p}<0.001$ when compared with normal, ${ }^{c} \mathrm{p}<0.001$ with Negative control.

Table 8: Estimation of GR

\begin{tabular}{lll}
\hline Groups & Treatment & mole GSH/mg protein \\
\hline Group I & Vehicle only & $42.84 \pm 0.47$ \\
Group II & Alcl $_{3}(100 \mathrm{mg} / \mathrm{kg})$ & $23.93 \pm 0.83^{*}$ \\
Group III & Rivastigmine $(0.3 \mathrm{mg} / \mathrm{kg})$ & $38.80 \pm 0.024^{\$}$ \\
Group IV & A.O $(200 \mathrm{mg} / \mathrm{kg})$ & $27.78 \pm 0.66^{\$ \mathrm{a}}$ \\
Group V & A.O $(400 \mathrm{mg} / \mathrm{kg})$ & $34.82 \pm 0.64^{\$ \mathrm{c}}$ \\
\hline
\end{tabular}

GR: Glutathione reductase, ${ }^{\$} \mathrm{p}<0.001$ with positive control, ${ }^{\mathrm{a}} \mathrm{p}<0.001$ with

standard, ${ }^{*} \mathrm{p}<0.001$ when compared with normal, ${ }^{c} \mathrm{p}<0.001$ with Negative control.

For estimation of lipid peroxidation MDA

Table 5 and Figure 5 reveals the \% increment of lipid peroxidase observed in A.O (400 mg/kg) dose as compared with that of standard drug was found to be $96.8 \%$.

\section{For estimation of SOD}

Table 6 and Figure 6 reveals the \% reduction of SOD observed in A.O (400 mg/kg) dose as compared with that of standard drug was found to be $99 \%$.

\section{For estimation of catalase}

Table 7 and Figure 7 reveals the \% reduction of catalase observed in A.O (400 mg/kg) dose as compared with that of standard drug was found to be $97 \%$.

\section{For estimation of GR}

Table 8 and Figure 8 reveals the \% reduction of GR observed in A.O (400 $\mathrm{mg} / \mathrm{kg}$ ) dose as compared with that of standard drug was found to be $89 \%$.

\section{Histopathological results of brain}

After sacrifice of all the animals, their brains were dissected out and fixed in $10 \%$ neutral formalin. The tissues were processed in the usual way for paraffin embedding and sections were mainly stained with Hematoxylin and Eosin for histopathology (20x) studies. From the Figure 9, the section of brain of normal rat's revealed presence of plaque and neurofibrillary tangles with cell degeneration, while from the figure 10, those groups treated with rivastigmine showed cell restoration similar to normal control group.

\section{DISCUSSION}

In the present study, the neuroprotective effect of alcoholic A. occidentale extract was investigated in aluminum chloride [13] induced Alzheimer's disease. Since aluminum chloride induced Alzheimer's diseasegenerally preferred appropriate model for the early onset of senile dementia, we used the above model for disease induction [14]. The extract used proved to have neuroprotection as an evidence of improvement in the neurological score of AchE, lipid peroxidation, glutathione, catalase, GR, SOD, protein. The purified and dried yield of alcoholic $A$. occidentale extract was subjected for the acute toxicity study to determine the therapeutic dose using albino rats in a controlled environment. Acute toxicity studies were performed according to the OECD 423 guidelines. The extract was administered through oral route to different groups of rats using oral feeding

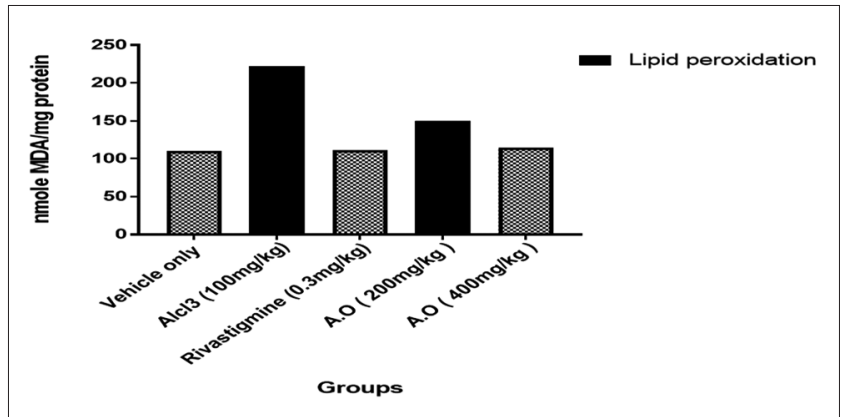

Fig. 5: Estimation of lipid peroxidation malondialdehyde

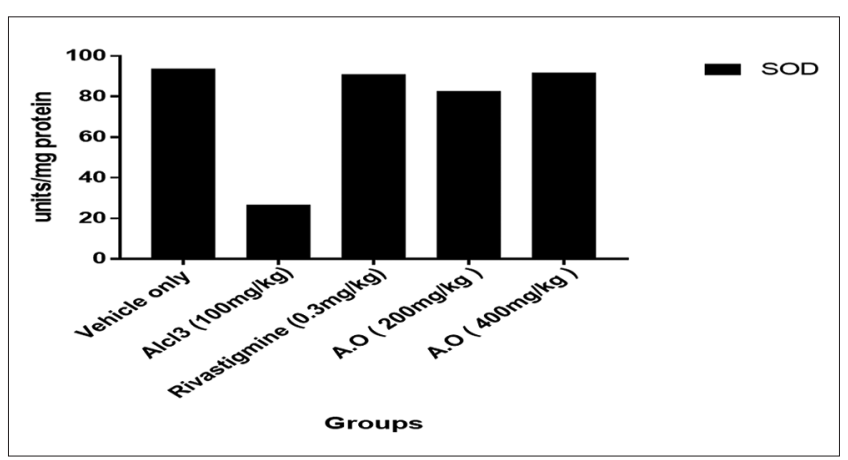

Fig. 6: Estimation of super oxide dismutase

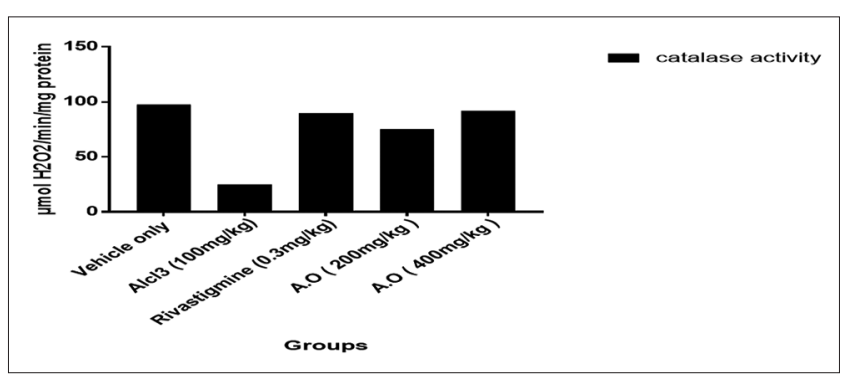

Fig. 7: Estimation of catalase

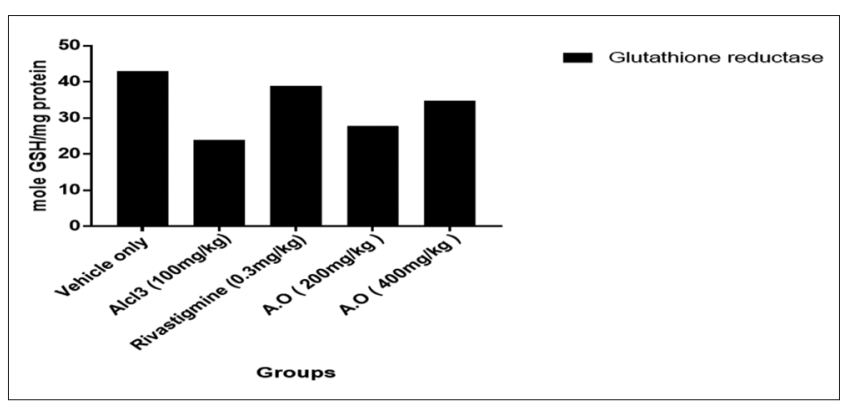

Fig.8: Estimation of glutathione reductase

needle (22 gauge). No deviation from normal behavioral pattern was observed. The observation was done continuously for 14 days, and mortality was not observed in any of the drug-treated group; hence, it was confirmed that the test drug alcoholic $A$. occidentale extract is practically nontoxic in normal rats and fall under the category of class $\mathrm{V}$ drugs, according to OECD guidelines. $1 / 10^{\text {th }}$ of dose was considered therapeutic dose and to identify the dose-dependent action the $200 \%$ of therapeutic dose was considered maximum dose for further pharmacological evaluation in animal model. Lower dose (200 mg/kg) and higher dose (400 mg/kg). 


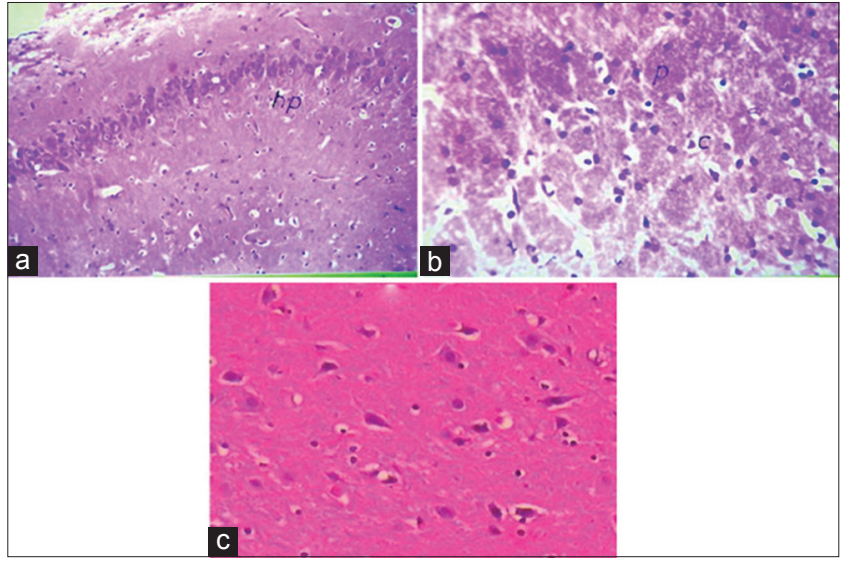

Fig. 9: Histopathology results of the brain, (a) Image of the brain section of a normal control rats (Group I) showing normal histological structure of the hippocampus, (b) Image of brain section of positive controlled group (Group II) showing plaque in hippocampus, (c) Section of brain of rats given Alcl3 without any treatment showing neurofibrillary tangles

Higher doses of alcoholic A. occidentale extract $400 \mathrm{mg} / \mathrm{kg}$ elicited neuroprotective activity when compared to lower dose $200 \mathrm{mg} / \mathrm{kg}$. This may be attributed to the presence of flavonoids, alkaloids, steroids, tannins, and minerals of $A$. occidentale fruit. Free radicals have been implicated in Alzheimer's and reperfusion-induced neuronal injury [15]. Free radicals promote lipid peroxidation [16] which results in the alteration in permeability and fluidity of the membrane. Reactive oxygen species (ROS) produces MDA, an end product of lipid peroxidation. MDA reacts with thiobarbituric acid and is thus estimated as thiobarbituric acid reactive substances (TBARS). Therefore, in the present study MDA was estimated using TBARS assay to estimate the extent of ROS formation. It is well reported that overproduced free radicals are detoxified by endogenous antioxidants. Glutathione is considered a central component in the antioxidant defenses of cells. It acts both to directly detoxify ROS and as a substrate for various peroxidises [17]. Aluminum is a potent choline toxin where it gains high affinity to transferrin expressed in the blood-brain barrier. On entering the brain, it induces inflammatory responses, slows down axonal transport, inhibits long-term potentiation, and causes structural abnormalities, thereby causing a decrease in the levels of acetylcholine at the synaptic cleft [18]. The results of this study indicate that chronic administration of aluminum chloride results in progressive deterioration of spatial memory and motor in coordination elicited through behavioral parametric estimations in elevated plus maze and Rota-rod paradigms.

In the elevated plus maze, on the $20^{\text {th }}$ day the ITL was taken and there was no significant variation. Normal control $\left({ }^{*} \mathrm{p}<0.001\right)$ and A. occidentale extract-treated $(200 \mathrm{mg} / \mathrm{kg})$ and $(400 \mathrm{mg} / \mathrm{kg})$ rats entered closed arm quickly and the mean retention latencies $\left(1^{\text {st }}\right.$ RTL and $2^{\text {nd }} \mathrm{RTL}$ ) to enter the closed arms on days 21 and 42 were shorter when compared to ITL. Aluminum chloride-treated $\left({ }^{\$} \mathrm{p}<0.001\right)$ rats showed no variation in mean retention latency on the $21^{\text {st }}$ and $42^{\text {nd }}$ day when compared to pre-trained animals ITL on the $20^{\text {th }}$ day. This shows cognitive impairment of aluminum chloride-treated animals. In Rotarod apparatus, the fall off time is being recorded for each group of animal and is known to observe on the $20^{\text {th }}$ day as initial fall off time. Standard $\left({ }^{\mathrm{a}} \mathrm{p}<0.001\right)$ A. occidentale extract $(200 \mathrm{mg} / \mathrm{kg}$ and $400 \mathrm{mg} /$ $\mathrm{kg}$ ) showed decrease in fall off time on the $21^{\text {st }}$ day and $42^{\text {nd }}$ day after training. Positive control $\left({ }^{s} \mathrm{p}<0.001\right)$ showed an increase in fall of time when compared to initial fall off time. This shows neurological deficit elicits motor in coordination.

In this study, chronic administration of aluminum chloride resulted in marked oxidative stress as indicated by increase in lipid peroxidation,

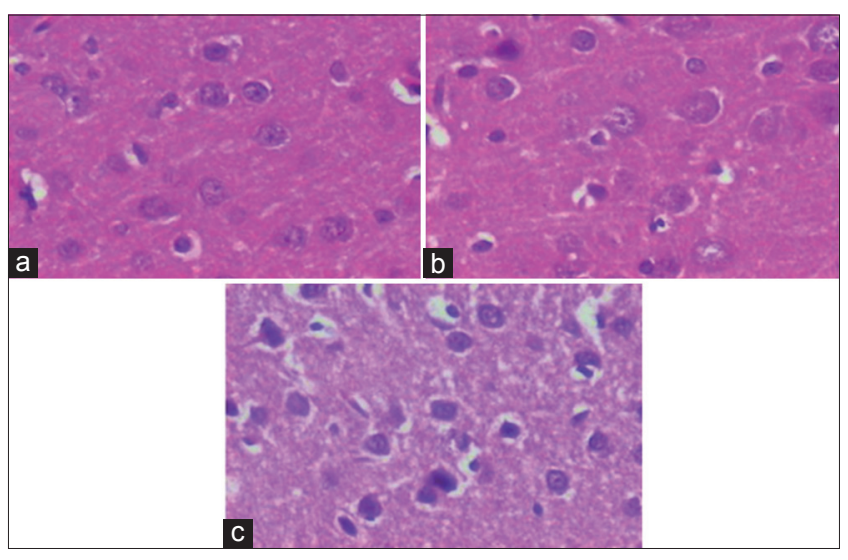

Fig. 10: (a) A section of brain of rat treated with rivastigmine $(0.3 \mathrm{mg} / \mathrm{kg})+$ Alcl3 for 20 days as a protection against AD, showing neurons i.e., more or less like normal group, (b) Section of brain treated with $\mathrm{Alcl}_{3}+200 \mathrm{mg} / \mathrm{kg}$ of $A$. occidentale extract for $\mathbf{4 2}$ days as a protection against $\mathrm{AD}$, showing neurons, i.e., more or less like normal group, (c) Section of brain treated with $\mathrm{Alcl}_{3}+400 \mathrm{mg} / \mathrm{kg}$ of $A$. occidentale extract for 42 days as a protection against $A D$, showing neurons, i.e., more or less like normal group

decrease in reduced glutathione levels, catalase, and superoxide dismutase and glutathione- $S$-transferase activity in the positive control group animals. This could be due to the reduced axonal mitochondria turnover, disruption of Golgi and reduction of synaptic vesicles induced by aluminum treatment which results in release of oxidative products such as MDA, carbonyls, peroxynitrites and enzymes like superoxide dismutase within the neurons [19].

In the present study, alcoholic extract of $A$. occidentale fruit resulted in an increase in acetylcholine levels and its anti-oxidants proved to scavenge free radicals and helped in treating the disease. Chronic administration of alcoholic A. occidentale extract $(200 \mathrm{mg} / \mathrm{kg})$ and $(400 \mathrm{mg} / \mathrm{kg})$ proved a marked increase in level of acetylcholine compared to the positive control $\left({ }^{\$} \mathrm{p}<0.001\right)$. Aluminum chloride-administered rats showed a great decline in acetylcholine levels when compared to normal control $\left({ }^{*} \mathrm{p}<0.001\right)$. This proves that the $A$. occidentale fruit extract showed evidence for neuroprotection.

Aluminum chloride induced (positive control) rats showed a significant increase in aluminum in the cortex of the brain when compared to normal control $\left({ }^{*} \mathrm{p}<0.05\right)$, standard and A. occidentale extract $(200 \mathrm{mg} / \mathrm{kg})\left({ }^{\mathrm{s} a} \mathrm{p}<0.05\right)$-treated rats. Chronic administration of aluminum chloride showed a marked increase in free radical generation and increase in MDA levels, causing lipid peroxidation when compared to normal control $\left({ }^{*} \mathrm{p}<0.001\right)$ and treatment with alcoholic A. occidentale extract $(200 \mathrm{mg} / \mathrm{kg})$ and $(400 \mathrm{mg} / \mathrm{kg})$ showed decrease in levels of MDA compared to the positive control ( $\left.{ }^{\$} \mathrm{p}<0.001\right)$. Rivastigmine was used as a standard drug as it the only proven pharmacological therapy for symptomatic treatment of $\mathrm{AD}$ [20]. Treatment of AD rats with rivastigmine as a protective agent led to an improvement in the oxidative stress as represented by a significant increase in acetylcholine levels as well as improving results in behavioral and biochemical parameters when compared with AD induced diseased rats. Aluminum leads to oxidative stress which caused a decrease in antioxidants SOD, glutathione, catalase, glutathione, and GR in the positive control. Treatment with alcoholic A. occidentale extract $(200 \mathrm{mg} / \mathrm{kg})$ and $(400 \mathrm{mg} / \mathrm{kg})$ showed an increase in the levels of the antioxidants as shown in respectively, when compared to a positive control $\left({ }^{\$} \mathrm{p}<0.001\right)$.

Rivastigmine and test drug (A. occidentale fruit extract) showed results that were confirmed by the histopathological findings of brain tissues, wherein amyloid plaques that are formed from $\mathrm{AlCl}_{3}$ administration disappeared in treated rats when compared to disease rats. The 
efficacy of rivastigmine in the treatment of dementia, where it binds to AchE molecule in the precursor if Ach in an irreversible manner. A. occidentale fruit extract also inhibits amyloid formation by directly inhibiting $A \beta$ aggregation, metal chelation, antioxidant property, hypocholesterolemic effect, modulating-secretase activity, antiinflammatory property and modulating the JNK signaling pathways. All these effects may also contribute to its neuroprotective effect. This also explains the fact that aluminum chloride treatment caused a marked reduction in the acetylcholinesterase activity which was restored by chronic papaya leaf treatment. Our results also support that $A$. occidentale extract decreased the concentration of aluminum in hippocampus particularly. The hippocampus and dentate gyrus of the brain are mainly responsible for memory formation. This could be the only mechanistic pathways for the neuroprotective effect of A. occidentale fruit in cognitive dysfunction of aluminum-treated rats. From the epidemiologic and experimental studies reported, there is ample evidence which supports the fact that aluminum plays a pivotal role in the neuropathology of $\mathrm{AD}$.

This study validates the fact that chronic exposure to aluminum causes cognitive dysfunction and related oxidative damage. It clearly demonstrates that $A$. occidentale fruit has a neuroprotective effect against aluminum-induced behavioral and biochemical changes and further warrants the need for molecular studies to elucidate the mechanisms underlying the protective effects of $A$. occidentale. From the acute toxicity study, it was concluded that the test drug A. occidentale is practically non-toxic on oral administration. A number of models have been used for the study of Alzheimer's disease. In the present study of aluminum chloride administration proved synergistic effects on accelerating the development and progression of Alzheimer's disease. Long-term oral administration of aluminum chloride for 42 days caused Alzheimer's disease in rodent model which involves the pathological, neurochemical, behavioral, and biochemical alterations in the levels of acetylcholinesterase activity, protein, catalase, SOD, MDA, GH. Pre-treatment with $A$. occidentale significantly reverted the $\mathrm{Alcl}_{3}$ induced changes in rats. The constituents of $A$. occidentale has volatile compounds - resorcinolic acid, anacardic acids, carotenoids, vitamin $\mathrm{C}$, phenols, and tannin and phenolic constituents - anacardic acids, cardols, cardanols having a powerful anti-oxidant activity. The presence of the above constituents might be responsible for neuroprotective effect of $A$. occidentale against $\mathrm{Alcl}_{3}$ induced in rats.

The present study indicates the cumulative protective effect of A. occidentale with the high level of antioxidant activity against $\mathrm{AlCl}_{3}$ induced spatial memory deficit and further confirms the beneficial effect of antioxidants in neurodegenerative disorder such as AD. Thus, it might be concluded that $A$. occidentale, through its antioxidant potential, provided neuroprotection against $\mathrm{AlCl}_{3}$ induced cognitive deficits and oxidative damage in rats. A preventive measure addressing the cognitive decline can be expected to have a therapeutic influence on the aging population by reducing the well-recognized prevalence of Alzheimer's disease. The A. occidentale treatment showed improvement in memory. Further investigation into the role and mechanisms of antioxidant action are needed to be determined which can be an effective remedy for Alzheimer's disease. This study reveals that $A$. occidentale, as a powerful antioxidant for treating cognitive deficits, oxidative damage [21], and morphological changes in the diseased rats. Thus, it may have a good therapeutic value for the treatment of Alzheimer's disease.

\section{ACKNOWLEDGMENT}

The authors declare that there is no acknowledgment for this article.

\section{REFERENCES}

1. Brookmeyer R, Johnson E, Ziegler-Graham K, Arrighi HM. Forecasting the global burden of Alzheimer's disease. Alzheimers Dement 2007;3(3):186-91

2. Bharathi, Shamasundar NM, Sathyanarayana Rao TS, Dhanunjaya Naidu M, Ravid R, Rao KS. A new insight on Al-maltolate-treated aged rabbit as Alzheimer's animal model. Brain Res Rev 2006;52(2):275-92.

3. Akinwale T. Cashew apple juice: Its use in fortifying the nutritional quality of some tropical fruits. Eur Food Res Technol 2000;211(3):205-7.

4. Okonkwo TJ, Okorie O, Okonta JM, Okonkwo CJ. Sub-chronic hepatotoxicity of Anacardium occidentale (Anacardiaceae) inner stem bark extract in rats. Indian J Pharm Sci 2010;72(3):353-7.

5. Giordano R, Costantini S. Some aspects related to the presence of aluminium in waters. Ann Ist Super Sanita 1993;29(2):305-11.

6. Tédong L, Dzeufiet PD, Dimo T, Asongalem EA, Sokeng SN, Flejou JF, et al. Acute and subchronic toxicity of Anacardium occidentale Linn (Anacardiaceae) leaves hexane extract in mice. Afr J Tradit Complement Altern Med 2006;4(2):140-7.

7. Paulbabu K, Singh KD, Prashanti P, Padmaja M. Neuroprotective potential and efficacy of neurodegenerative disorders of fruit extract of aegle marmelos. Int J Pharm Pharm Sci 2014;7:155-9.

8. Kassab RB, Bauomy AA. The neuroprotective efficiency of the aqueous extract of clove (Syzygium aromaticum) in aluminium-induced neurotoxicity. Int J Pharm Pharm Sci 2014;6(5):503-8.

9. Bjertness E, Candy JM, Torvik A, Ince P, McArthur F, Taylor GA, et al. Content of brain aluminum is not elevated in Alzheimer disease. Alzheimer Dis Assoc Disord 1996;10(3):171-4.

10. Harborne JB, Baxter H. The Handbook of Natural Flavonoids. Vol. 2. Washington, DC: Wiley Interscience; 1999. p. 1-114.

11. Nade VS, Kawale LA, Shendye NV, Patil NR. Protective effect of nebivolol on aluminium-induced neurobehavioral and biochemical alterations in rats. Int J Pharm Pharm Sci 2014;6(5):386-91.

12. Carageorgiou H, Sideris AC, Messari I, Liakou CI, Tsakiris S. The effects of rivastigmine plus selegiline on brain acetylcholinesterase, (Na, K)-, Mg-ATPase activities, antioxidant status, and learning performance of aged rats. Neuropsychiatr Dis Treat 2008;4(4):687-99.

13. McLachlan DR, Bergeron C, Smith JE, Boomer D, Rifat SL. Risk for neuropathologically confirmed Alzheimer's disease and residual aluminium in municipal drinking water employing weighted residential histories. Neurology 1996;46(2):401-5.

14. Krewski D, Yokel RA, Nieboer E, Borchelt D, Cohen J, Harry J, et al. Human health risk assessment for aluminium, aluminium oxide, and aluminium hydroxide. J Toxicol Environ Health B Crit Rev 2007;10 Suppl 1:1-269.

15. Ellman GL, Courtney KD, Andres V Jr, Feather-Stone RM. A new and rapid colorimetric determination of acetylcholinesterase activity. Biochem Pharmacol 1961; 7:88-95

16. Globus MY, Alonsa O, Dietrich WD, Busto R, Ginesberg MD. Glutamate release and free radical production following brain injury: Effects on post traumatic hypothermia. J Nuerochem 1995;65(4):1704-11.

17. Halliwell B. Reactive oxygen species in living systems: Source, biochemistry, and role in human disease. Am J Med 1991;91(3C):14S-22.

18. Dringen R. Metabolism and functions of glutathione in brain. Prog Neurobiol 2000;62(6):649-71.

19. Kawahara M, Muramoto K, Kobayashi K, Mori H, Kuroda Y. Aluminum promotes the aggregation of Alzheimer's amyloid beta-protein in vitro. Biochem Biophys Res Commun 1994;198(2):531-5.

20. Sharma AC, Kulkarni SK. Evaluation of learning and memory mechanisms employing elevated plus-maze in rats and mice. Prog Neuropsychopharmacol Biol Psychiatry 1992;16(1):117-25.

21. Okechukwu NP. Hypoglycemic and free radical scavenging activity of partially purified fraction E from DCM stem extract of Cosinium fenestratum. Asian J Pharm Clin Res 2012;5(4):30-6. 